Veterinary Faculty, Department of Protozoology, Medical Arthropodology and Control of Parasitic Diseases, University of Ankara

Prof. Dr. Mihri Mimioğlu

\title{
THE PRESENCE OF EIMERIA BAREILLYII (Gill, Chhabra and Lall, 1963) IN BUFFALO IN TURKEY
}

\author{
Fahri Sayn*
}

Summary : This is a report which is concerning with the presence of $E$. bareillyi (Gill, Chhabra and Lall, 1963) in water buffalo (Bubalus bubalis) in Turkey. The oocysts of this species were found in the intestinal content of 1 out of $50(2 \%)$ buffalocs originated from the province of Adapazari. The morphological characteristics of sporulated oocysts were discus et in the paper.

\section{Türkiye'de Mandalarda Bulunan Eimeria bareillyi (Gill, Chhabra ve Lall, I963) üzerinde Incelemeler}

Ózet : Onccki araştırmalarımızla Türkiye’de, mandalarda, varlı̆̆ını bildirdiğimiz 11 adet Eimeria türünden başka, Eimeria bareillyi adı verilen diğer bir türün de bulunduğu anlaşılmıştır. Bu türün oocystlerine, Adapazarı'ndan Ankara mezbahasına kesim için getirilen 50 mandadan 1 tanesinin (\%2) dışkısında raslanmıştır.

E. bareillyi'nin oocystcleri armut biçiminde, sarımsı esmer renktedirler. Cidarları düz, çift katlı ve 1,2 mikron kalınlığa sahiptirler. Ince kutuplarında mikropil vardır ve bunun genişliği 4-5 mikrondur. Oocystlerin uzunluğu 24-29, genişliği 15-19 mikrondur. Bunlàr 22 C. de 3 günde sporlanmaktadırlar. Oocystlere ve sporocystlere ait protoplazma kalıntısı mevcuttur. Sporocystler 15-17 mikron uzunlukta ve 7-8 mikron kalınlıktadırlar (Şekil 1).

\section{Introduction}

Buffalo coccidia has called attention recently to investigators in several countries. The surveys of faecal samples for coccidia oocysts were carried out and the species which were found in Russia 19, India 2'4'12'15 and Turkey16 were already reported.

Eimeria bareillyi was found initially in India ${ }^{4}$. The oocysts of this species was obtained in the intestinal content of water buffaloes

* Professor at The Department of Protozoology, Medical Arthropodology and Control of Parasitic Discases, Veterinary Faculty, University of Ankara, Turkey. 
(Bubalus bubalis) in Bareilly, Izatnagar, Nagla and Utter Paradesh regions ${ }^{\prime}{ }^{4}$. It was observed in $5 \%$ of 305 buffaloes in these places ${ }^{2}$.

In addition an oocyst form from the faccal samplc of buffalo was described in Pakistan 1 and the name of Eimeria bubalis was uised for it 20 . This species showed similar morphological characteristics . to Eimeria bareillyi. Therefore E. bareillyi and E. bubalis were considered as one and the same speciess.

The purpose of the present paper is to report the occurrence of $E$. bareillyi in water buffalo in Turkey.

\section{Material and Methods}

This study is based on the examination of sporulated oocysts of $E$. bareillyi observed in the intestinal content of 1 out of 50 water buffaloes brought from Adapazari to Ankara meat plant to slaughter.

The faecal samples were obtained from rectums of apparently healthy animals. After washing and straining of the faecal samples, oocysts were concentrated by centrifugal flotation method with Sheather's suger solution for discovery. The sample which contained the oocysts of $E$. bareillyi was mixed with $2.5 \%$ Potassium Dichromate solution and placed in a thin layer in a Petri dish at room temperature to permit the oocysts to sporulate. The sporulated oocysts were concentrated by the method which was mentioned above prior to the study of their morphological characteristics. They were examined with Olympus microscope (Photomax) equipped with apochromatic plain objectives. The picture of the sporulated oocyst was drawn by camera lucidia.

\section{Results}

The oocysts of $E$. bareillyi occurred I out of $50(2 \%)$ faecal samples taken from apparently healthy animals. The number of the oocysts which present in each gram of facces was 50.

The oocysts of $E$. bareillyi are typically piriform with bluntly truncate small end (fig. I). Oocyst wall is smooth, homogenus, yellowish to darkish brown and composed of two layers. Outer layer is colorless and inner one darkish brown in color. It is 1.2 microns thick exccpt at the micropylar end where it is thinner. There is a micropyle at the small end. It is 4-5 microns in width. Twenty oocysts were $24^{-29}$ by $15^{-1} 9$ (average 27 by 17 ) microns. A few small granules were present inside of the micropyle in sporulated and unsporulated 
oacysts The oocysts required 3 days to complete their sporulations at 22 C. Oocyst residuum was present, but oocyst polar granule absent. Sporocysts were alongate ovoid and had stieda body at their small ends. They were $15^{-1} 7$ by $7-8$ (average 16 by 7 ) microns in dimension. Sporocyst residuum was present. Sporozoites were banana shapcd, each with a refractile spherical globule at its large end and somctimes one or two smaller globules.

\section{Discussion}

Twelve species of bovine coccidia were found in cattle and water buffalo in Turkey $(i 6, \mathrm{I} 7)$. Onc more species, $E$. bareillyi, recovered in buffalo is added to the list by this study.

$E$. bareillyi may be confused with $E$. bukidnonensis on account of its pear like oocysts. But our own observation showed that $E$. bareillyi and $E$. bukidnonensis were quite distinct. The oocyst of $E$. bukianonensis is larger than that of E. bareillyi and has a thick, radial stricted, single-rather than a double-- layered wall. Besides the sporulation time of $E$. bukidnonensis is longer than that of $E$ bareillyis'

6' ' ',' ${ }^{\prime} 10^{\prime} 12^{\prime}, 13$ ' 1 . It may be also confused with E. boris on account of the similarity on the dimensions and double layered wall of thcir oocysts. But $E$. bovis is distinguished quite easy by its oocyst which is broadly ovoid in shape and docs not have an oocyst resi-

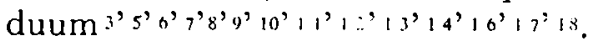

Our matcrial agrees with the descriptions given by Gill et al ${ }^{4}$ and Bhatia et al: from India.

\section{References}

I. Abdusselam, M. and Rauf, A. (1956): Coccidiosis of diomestic buffalo (Bubalus bubalis). Proc. 8th Pakistan Sci. Conf. Med. I956: 6 .

2. Bhatia, B. B., Pande, B. P., Chauhan, P. P. S. and Arora, G. S. (1968): A study on the sporulated oocysts of twelve Eimerian species in Indian buffalo (Bubalus bubalis). Acta Vet. Hungar. I8:1 I $5^{-1} 33$.

3. Davies, S. F., Joyner, L. P. and Kendall, S. B. (1963): Coccidiosis. Oliver and Boyd, Edinburgh X +264 pp.

4. Gill, B. S., Chhabra, M. B. and Lall, N. B. (1963): A newe species of coccidium-Eimcria bareillyi $n$. sp. from buffaloes. Arch. Protistenk. I 06: 57 I-574. 
5- Hammond, D. M. $\left({ }_{1964)}\right)$ Cocciaiosis of cattle; some unsolved problems, 3oth Fac. Honor Lect., Utah State Univ., Logan, Utah, $36 \mathrm{pp}$.

6. Joyner, L. P., Narton, C. C., Davies, S. F. M. and Watkins, C. V. (1966): The species of cocciaia occurring in cattle and sheep in the South West of England. Parasitology 56: $53^{\mathrm{I}-44^{\mathrm{I}} \text {. }}$

7. Lee, R. P. and Armour, J. (1 959): The coccidian oocysts of $\mathcal{N i}_{i-}$ gerian cattle. British Vet. J., I $_{5} 5: 6$ i7.

8. Levine, N. D. and Ivens, V. (1970): The coccidian parasites (Protozoa, Sporozoa) of ruminants. Illinois Biological Monographs 44, Univ. of Illinois Press, 278 F.p.

9. Levine, N. D. and Ivens, V. (1967): The sporulated oocysts of Eimeria illinoisensis n. sp and of other species of Eimeria of the ox. J. Protozool, 14: 351-360.

Io. Levine, N. D. ( $196 \mathrm{I})$ : Protozoan parasites of domestic animals and of man. Burges, Minneapolis, 412 pp.

I I . Nyberg, P. A. and Hammond, D. M. (1965): Description of the sporulated oocysts and sporozoits of four species of bovine coccidia. J. Parasit. 51: 669-673.

12. Patnaik, M. M. ( $\left.19^{65}\right)$ : On the coccidian infections of buffalo calves. A study of the oocysts. Agra Univ. J. Res. (Sci), 13:239-256.

13. Pelerdy, L. P. ( 1965$)$ : Coccidia and Coccidiosis. Akad, Kiado, Budapest. 657 pp.

14. Pellerdy, L. P. ( $\mathrm{Ig}_{63}$ ): Catalogue of Eimeriidea (Protozoa: Sporozoa). Akad. Kioda, Budapest, I6o pp.

I5. Ray, H. N. and Mandal, L. N. (I96I): On a new coccidium, E. ovoidalis n. sp., from buffalo calf and its experimental transmission to a cow calf. 48th Indian Sci. Cong. Part 3: 41 I (Zoology and Entomolgy section).

16. Sayın, F. (1968): The sporulated oocysts of Eimeria ankarensis $n$. $s p$, and of other species of Eimeria of Buffalo in Turkey and transmission of four specias of Eimeria from buffalo to cow calves. Ankara Univ. Vet. Fak. Derg., 15: 3-4, 282-300.

I 7. Saym, F. (1970): The species of Eimeria occurring in cattle in Turkey. Ankara Univ. Vet. Fak. Derg. I 7: 3, 310-326.

18. Supperer, R. (1952): Die Coccidien des Rindes in Osterreich. Oestr. Zool. 3: 591-60r. 
19- Yakimoff, V. L. (1933): La coccidiose des animaux domestiques dans L'Azerbaidjan (Transcaucasia). Ann. Soc. Belg. Med. Trop., I3: $93^{-1} 3^{\circ}$.

20. Yasin, S. A. and Abdusselam, M. (1958):Recent Contributions to Veterinary Parasitology in Pakistan. Bull. Off. Intern. Epizoot. 49 bis: $48 \mathrm{I}-49^{2}$.

Received $4 \cdot 4 \cdot 1973$
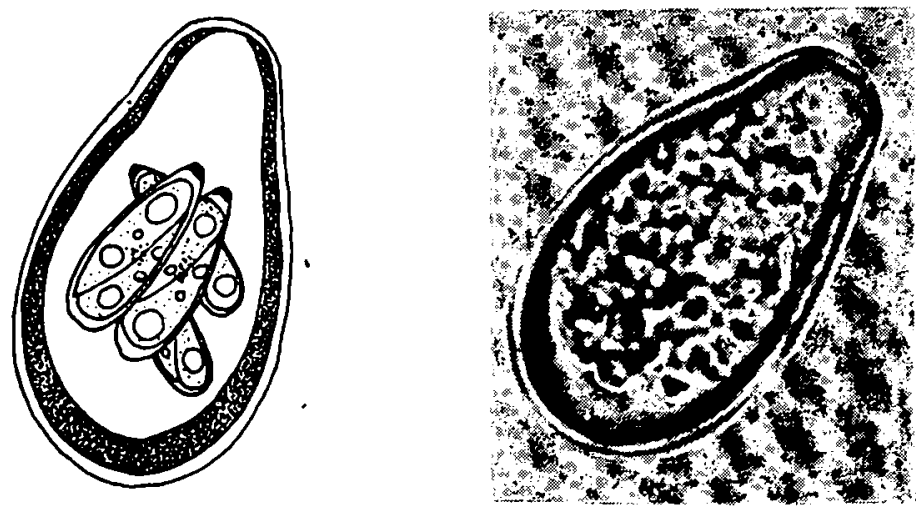

Fig. 1: Sporulated and unsporulated oocystes of Eimeria bareillyi X 1814 